\section{UNIVERSITY \\ of DEBRECEN}

FACULTY OF

HEALTH

NYÍREGYHÁZA

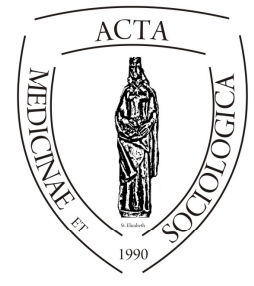

ACTA

MedSoc

VOlume 3.

2013

\title{
A speciális szükséglet lehetséges háttérté- nyezői egy 2011-es vizsgálat tükrében
}

\author{
Nagy Loránd
}

Hajdú-Bihar Megyei Területi Gyermekvédelmi Szakszolgálat

\section{Bevezetés}

A mai gyermekvédelem egyik kritikus pontja a speciális ellátás biztosításának kérdése. Napjaink gazdasági helyzetében, gyorsan változó jogszabályi környezetben, a gyermekek speciális ellátásának biztosítása nagy kihívást jelent a gyermekvédelmi szakemberek számára. A gyermek számára nem mindegy milyen színvonalú ellátást kap, ,talán a szolgáltatások hiányossága az egyik legkritikusabb pontja a speciális ellátás biztositásának" (Hajduné, 2007).

Úgy gondolom, hogy kiemelt jelentőséget kell tulajdonítani annak megismerésére, hogy milyen út vezet a speciális szükséglet megállapításához. Annak tükrében, hogy pontos ismeretekkel rendelkezzünk arról, hogy a speciális szükséglet mögött milyen háttérmechanizmusok munkálkodnak, csak célzott szolgáltatások segítségével tudjuk a gyermek speciális ellátását hatékonyan biztosítani.

Ebben a tanulmányban arra teszek kísérletet, hogy a speciális szükségletnek egy értelmezési keretet adva, rávilágítsak arra, hogy Hajdú - Bihar megyében a 2011. évben a szükséglet kialakulásában milyen tényezők játszhatnak szerepet. Egy külön tanulmány témája lehetne ha több évre, illetve országos viszonylatban vizsgálnánk ezeket a háttértényezőket. Remélem, hogy jelen tanulmány eredményeinek ismeretében talán majd megfogalmazódnak vitaindító gondolatok, amelyek a későbbiekben elősegítik a hatékony és eredményes szolgáltatásfejlesztést.

DOI: $10.19055 / \mathrm{ams} .2013 .4 / 11 / 7$ 


\section{A speciális szükséglet értelmezési kerete}

\section{A gyermekvédelem, mint a speciális szükséglet fogalmi kerete}

A speciális szükséglet definiálása elött mindenképpen szükségesnek tartom, hogy egy értelmezési keretbe helyezzük a szükségletet. A speciális ellátási igény a gyermekvédelmi szakellátással való érintettség során jelenhet meg, hiszen a megyei/fővárosi gyermekvédelmi szakértői bizottságok és az Országos Gyermekvédelmi Szakértői Bizottság kaptak jogosultságot arra, hogy a szükségletet kimondják, megállapítsák. A bizottságok végzik a szükséglet felülvizsgálatával kapcsolatos teendőket is.

A speciális szükséglet tehát a gyermekvédelem fogalomrendszerében értelmezhető, azon belül a gyermekvédelmi szakellátásba kerülés, vagy a szakellátásban eltöltött idő során jelenhet meg. Megjelenését befolyásolhatja számos tényező, mind a gyermekjóléti alapellátás során jelen lévő, mind a szakellátásban megjelenő tényező.

A gyermekvédelem olyan tevékenységek, eszközök és intézmények együttese, amely a gyermeki jogok védelmét, a gyermekek harmonikus testi, értelmi, érzelmi és erkölcsi fejlődését, családban történő nevelését, a veszélyeztetettség megelőzését, illetve megszüntetését, valamint a családjából már kiemelt gyermeknek a saját családba történő visszahelyezését célozza, és ezek által biztosítja a gyermekek számára azt a különleges védelmet, amit fizikai és szellemi érettségük hiánya indokol. Szélesebb értelmében idetartozik minden olyan, a gyermeket nevelő családok felé irányuló pénzbeli vagy természetbeni támogatás és szolgáltatás, amely segíti a szülőket abban, hogy gyermekeiket felnevelhessék, és ne alakuljon ki a gyermeket veszélyeztető helyzet a családban. A gyermekvédelmi szolgáltatások igénybevétele önkéntesen vagy hatósági kötelezéssel lehetséges. E szolgáltatások a gyermekjóléti alap- és a gyermekvédelmi szakellátásokra tagolódnak (Szikulai, 2004).

A gyermekvédelmi szakellátás a családjukból kiemelt gyermekek és fiatalok gondozása, nevelése (otthont nyújtó ellátás, utógondozói ellátás). A gyermekvédelmi szakellátás feladatait a nevelőszülők, a gyermekotthonok, a területi gyermekvédelmi szakszolgáltatást nyújtók, és az életkezdő fiatalok támogatása teljesíti. A gyermekvédelmi szakellátások célja az ideiglenes hatállyal elhelyezett, az átmeneti nevelésbe vett és a tartós nevelésbe vett gyermek otthont nyújtó ellátásának, a fiatal felnőtt további utógondozói ellátásának, valamint a szakellátást más okból igénylő gyermek teljes körü ellátásának biztosítása (Rácz - Szikulai szerk., 2006). 
Ebben az értelmezési keretben a veszélyeztetettségnek, a gyermek ebből fakadó kríziseinek nagy jelentősége van, amelynek a kezelésére, ha nincs hatékony megoldás, egyenes út vezethet a gyermekvédelmi szakellátásba kerüléshez, a speciális ellátási igény megjelenéséhez.

\subsection{A veszélyeztetettség értelmezési kategóriái}

A következő szempontokat tartom fontosnak:

- A veszélyeztetettség kifejezés olyan helyzetekre utal, melyek objektíve létező tulajdonságainál fogva ártalmasak a gyermek számára.

- A problémáknak a gyermekvédelemhez sorolása elsősorban a közpolitikai folyamat során dől el.

- A veszélyeztetettséggé minősítés döntő fontosságú kritériuma a gyermek, a szülők és az állam közötti viszony. Azok a helyzetek tartoznak a veszélyeztetettséghez, melyeket a társadalom úgy minősít, hogy nem tartoznak a normális problémák közé, és rendezésükhöz állami kontroll, egyben pedig a család autonómiájának korlátozása szükséges.

- Az a gyermek-szülő-állam viszony konkrét konstellációján múlik, hogy sor kerül-e közösségi cselekvésre, illetve hogy milyen típusú közcselekvést alkalmaznak. Ha a társadalom „,kivételesnek” minősíti a gyermek problémáját, akkor a problémát kezelő megoldások keresztülhatolnak a családi burkon és közvetlenül a gyermekre irányulnak. Ilyenkor a „,kivételes" problémát összefüggésbe hozzák a szülő felróható magatartásával, devianciájával, vagy egyszerüen úgy tekintik, hogy a szülö nem jelent kellö garanciát a kockázat kezelésére.

- A helyzetek ,gyermekvédelemre tartozóságának” kritériumait a kialakított társadalmi konstrukció (a veszélyeztetettség-konstrukció) tartalmazza. A veszélyeztetettség- konstrukció végső soron azt fejezi ki, hogy valamely problémahelyzet kezelése nem bízható a szülőre, hanem szükség van olyan közcselekvésre, amely a család autonómiáját korlátozva szervezi a probléma megoldását (Szöllősi, 2003).

\subsection{A gyermekvédelmi szakellátásba kerülés lehetséges okai}


A gyermekvédelmi szakellátással azok a gyermekek kerülnek kapcsolatba, akiknek veszélyeztetettségét az alapellátás eszközeivel kezelni, megszüntetni nem lehetett. Veszélyeztetettség az is, ha szülöi felügyelet, törvényes képviselő nélkül marad a gyermek. A szakellátásba kerülés okainak vizsgálata rávilágíthat arra, milyen objektív tényezők játszanak szerepet a gyermek veszélyeztetésében.

Neményi Mária és Messing Vera 2005-benös évben átfogó kutatást végzett a gyermekvédelmi gondoskodásba került gyermekek helyzetére vonatkozóan. Egy országos, három kiválasztott korcsoport - csecsemőkorúak, iskolába lépők, kamaszok - esetében teljes körü mintán történő, kérdőíves módszerrel (pontosabban: az általunk összeállított adatgyüjtő ív segítségével) végeztek összehasonlító vizsgálatot. Kíváncsiak voltak arra, milyen fó okok állnak a gyermekvédelmi gondoskodásba helyezés mögött. A beutalási okokat fökomponens-elemzés segítségéve boncolgatták, amely megerösítette azt a hipotézisüket, hogy bizonyos okok jellemzően együtt járnak, tehát jól kirajzolható az okok együtt járásának mintázata.

- A legnépesebb csoport, olyan vegyes csoport, ahol a bekerülési indokok között egyformán szerepet játszott a gyermek elhanyagolása, a család rossz szociális körülményei, a szülö szenvedélybetegsége, valamint a gyermek elhagyása.

- A második legnagyobb csoporthoz azok a gyermekek tartoznak, akik bekerülési indokául alapvetően a rossz szociális körülményeket, és - az ebből következő -szülői elhanyagolást nevezték meg az illetékes szakemberek.

- A következő az az okcsoport, amikor a gondoskodásba kerülés mögött alapvetően a szülők betegsége vagy halála állt.

- A negyedik csoportba olyan gyermekek kerültek, akik gondozásba kerülése egyértelműen saját deviáns viselkedéséből következett.

- Végül a legkisebb csoportot azok a gyerekek alkotják, akiket szenvedélybeteg (alkoholista, kábítószerfüggö) szülei bántalmaztak, esetleg szexuálisan is zaklattak (Neményi-Messzing, 2005).

\subsection{A gyermeket érö lehetséges traumatizáló hatások}


A fenti veszélyeztető tényezők traumatizáló hatása vitathatatlan, és ezek a hatások többnyire a nevelésbe vételt megelőző időszakból származnak. Kálmánchey Márta (2001) szerint a jellemzően előforduló traumatizáló hatások négy csoportba oszthatók:

- A nevelésbe vételt megelőző időszakból származó a lelki sérülések (elhanyagolás, bántalmazás).

- A nevelésbe vétel traumája (veszteség).

- A nevelőotthoni életből fakadó problémák (hospitalizáció).

- A nevelőszülői elhelyezés jellemző nehézségei (alkalmazkodás, elfogadás).

Felmerülhet a kérdés, hogy egy gondozási hely adekvátan tudja e kezelni ezeket a traumákat. Mi történik olyankor, ha a nevelőszülő nem rég végezte el a tanfolyamot és tapasztalatlan, vagy a gyermekotthonban nincs pszichológus, és ezáltal nem biztosítható a terápia?

A gyermekvédelem oldaláról ilyenkor ellátási diszfunkció jelentkezik, amely nem más, mint a gyermek úgynevezett másodlagos veszélyeztetése. Az adott szituációban az ellátási diszfunkció olyan ismétlődő vagy egyszeri cselekvést, szükséges beavatkozás hiányát vagy éppen a rendszerben lévő intézményi hiányosságot (,ellátási ür”) jelent, mely a gyermek mindenek felett álló érdekeivel ellentétes, és egyszersmind jogait is sérti (Bálint, 2007).

Látható, hogy a szakellátásba kerülés veszélyeztető helyzetei mögött számos traumatizáló tényező állhat. Felmerül a kérdés, hogy ezekben a helyzetekben a gyermekek milyen megküzdési stratégiákat alkalmaznak, és azok szocializáción keresztüli rögzülése mennyire határozza meg a hatékony problémamegoldást.

Szőtsné Karkus Zsuzsanna és szerzőtársai (2007) kutatásukban a megküzdés és szorongás tekintetében azt az eredményt kapták, hogy a megküzdési készségek terén jelentős elmaradást tapasztaltak a gyermekvédelmi gondoskodásban élő 16-20 éves fiatalok esetében a családban élő serdülőkhöz képest. Az érzelmi kontroll hiánya miatt jellemző rájuk a negatív következmények iránti szenzitivitás és a depresszióra való hajlam, valamint gyakoriak az agresszív megnyilvánulások, melyek irányulhatnak mások vagy önmaguk felé. Interperszonális repertoárjuk fejletlensége nyilvánvalóan összefügg érzelmi problémáikkal; nem képesek szereteten alapuló, jól müködő kapcsolatokat kialakítani. 
A gyermekvédelmi gondoskodásban élő gyermekek megküzdési kapacitás szempontjából elmaradnak a családban felnövő fiatalokhoz képest, amelyet meghatároznak azok a traumatizáló tényezők, amelyek a gyermek veszélyeztetettségi helyzetét megalapozzák. Szakellátásba kerüléskor számos objektív veszélyeztetettségi tényező azonosítható, de emellett fontos a gyermek ezek talaján megélt traumáinak kezelése annak érdekében, hogy a későbbiekben ezek a problémák ne halmozódjanak, ne induljon el a gyermek az un. „speciális” tünetképződés útján.

\section{A speciális szükséglet fogalma}

Az előzőekben a speciális szükségletnek a helyét próbáltam meghatározni a gyermekvédelemi kulcsfogalmak kontextusában. Megvizsgáltam, hogy a szükséglet milyen kapcsolatban állhat a gyermekvédelem olyan fogalmaival, mint a veszélyeztetettség, szakellátásba kerülés, vagy a gyermek belső erőforrásai. A gyermek traumatizált helyzetét ebben a viszonylatban kulcsfogalomnak tartom. A következőkben a speciális szükséglet értelmezéséhez nyújtanék áttekintést.

A gyermekvédelmi szakellátás egyik legvitatottabb kérdése a speciális szükségletü gyermekek körének, csoportjainak meghatározása, valamint az őket ellátó intézmények, intézményrendszer kialakítása.

A hosszas szakmai vita után kialakított speciális szükségletü gyerekek csoportjai:

- a súlyos pszichés,

- illetve a súlyos disszociális tüneteket mutató,

- valamint a pszichoaktív szerekkel érintett gyerekek.

Ezek csak gyüjtőfogalomnak használhatók, hiszen minden csoporton belül számos alcsoport, problématípus különíthető még el (Molnár-Radoszáv, 2007).

A Fővárosi Módszertani Gyermekvédelmi Szakszolgálat módszertani tevékenysége keretében 2009 szeptemberében alakította meg a Speciális Ellátás Módszertani Munkacsoportját. A szakemberek véleménye az volt, hogy a jelenlegi szabályozás probléma-profiljainak további differenciálására van szükség, annak érdekében, hogy az eltérő szükségletek kielégítésére adekvát ellátási formák szülessenek.

Speciális szükségletünek tekinthetjük tehát azokat a gyermekeket/ fiatalokat akik 
1. pszichoaktív szert használnak,

2. klasszikus pszichiátriai kórkép gyermekkori megnyilvánulásaiban szenvednek (esetenként pszichotikus állapotban lévők),

3. magatartási és beilleszkedési zavarokkal, antiszociális viselkedésformákkal küzdenek,

4. érzelmi élet és impulzus kontroll zavarokkal küzdenek (Speciális Ellátás Módszertani Munkacsoport, 2011).

A speciális szükséglet értelmezése eddig objektív kritériumok alapján történt, azonban számos szubjektív tényező is meghatározhatja, hiszen komplex minősítési folyamat eredményeként nyeri el jelentéstartalmát. Ezek alapján nem mindegy, hogy mennyiben és hogyan érzékelik a gyermekkel kapcsolatban állók a probléma súlyát. Fontos, hogy miként látják a szakemberek saját szakmai kapacitásuk határait. Figyelembe kell venni, hogy milyen tartalmú és terjedelmü szakmai illetékességet tulajdonítanak a speciális ellátásnak, az azt biztosító intézménynek. Fontos tudni, hogy egyáltalán létezik-e, hozzáférhető-e a speciális ellátás, és mennyire erősek a problémás viselkedésű gyermekhez füződő kapcsolati-kötődési szálak (Józsa, 2007a). Hasonlóképpen a speciális szükséglet szubjektív tényezőihez, a speciális ellátás értelmezése is komplex minősítési folyamat eredménye (Józsa, 2007b).

A veszélyeztetettség, a szükséglet és az ellátás értelmezése alapvetően meghatározza a gyermekkel történő segítő folyamatot. A gyermekvédelem rendszerében az alap- és szakellátás oldaláról megjelenő ellátási diszfunkció is jelentős mértékben hozzájárulhat a másodlagos veszélyeztetéshez. A szakellátásba kerülés a gyermeknél mindig súlyos akcidentális krízis következtében történik meg, noha a problémák halmozódását az alapellátás keretein belül kellene elkerülni. Ez mind vezethet oda, hogy a szakellátás fog megbirkózni a traumatizáló tényezők nyomán kialakult tünetekkel, amelyek mértéke elérheti azt a szintet, hogy azt már speciális szükségletként kell értékelni. (Herczog, 2007) 


\section{A speciális szükséglet lehetséges háttértényezői- nek vizsgálata 2011-ben}

\section{Módszertani háttér}

2011. év során a Hajdu-Bihar Megyei Gyermekvédelmi Szakértői Bizottság (továbbiakban: Szakértői Bizottság) által elkészített Szakvéleményekből származnak a következő adatok.

A kutatásom célja az volt, hogy rálássak arra, hogy 2011. évben a Hajdú-Bihar megyei speciális szükségletüvé nyilvánítások hátterében milyen tényezők játszanak szerepet, milyen hatásmechanizmusok vezetnek ahhoz, hogy egy gyermek esetében megállapításra kerül a speciális szükséglet, valamint melyek voltak jellemzően azok a típusos tünetek, amelyek meghatározzák a szükségletet.

Feltételezem hogy a tünetek sokszínüségének hátterében több tényezőnek kell szerepet játszania. A gyermek, életútja valamint a szakellátásban eltöltött idő alatt, különböző hatásoknak van kitéve, keresztülmegy az elsődleges és másodlagos szocializáción. Azt, hogy ezeket a hatásokat hogyan dolgozza fel, a szocializáció által elsajátított, belsővé tett minták határozzák meg. Ezért úgy gondolom, hogy a családi diszharmóniának jelentős szerephez kell jutnia a speciális szükséglet kialakulásában.

Kutatási módszerként a dokumentumelemzést választottam, hiszen a Szakértői Bizottság szakvéleménye az a kulcsdokumentum, amely megállapítja/ kizárja a gyermek speciális szükségletét. Az előzményekből feltérképezhető a gyermek életútja, a részvizsgálatokból pedig kiderül, hogy a tünetek hátterében milyen hatásmechanizmusok dolgoznak, milyen segítségnyújtásra van ezért szükség. A javaslat részben pedig nevesítik, hogy a gyermek speciális szükségletü-e, vagy sem, illetve a konkrét segítségnyújtási formák nevesítését is itt találjuk. A kutatási módszer ezen formája tehát teljes körü információt nyújt a gyermekről, hiszen a részvizsgálatokat végző szakemberek véleményük kialakítása során találkoznak a gyermekkel, annak hozzátartozóival, illetve a velük kapcsolatban álló szakemberekkel is. 
A mintába a 2011. évben a Hajdu-Bihar Megyei Gyermekvédelmi Szakértői Bizottság által speciális szükségletűvé nyilvánított gyermekek szakvéleményei kerültek be.

Összesen 55 főnél került sor speciális szükséglet vizsgálatára 2011-ben. A bizottság 46 esetben állapította meg a speciális ellátási igényt. Ebben a számban a speciális szükséglet kontroll vizsgálata során történő megállapítások is benne vannak.

30 esetben történt újonnan speciális szükséglet megállapítása (tehát a kontrollvizsgálatok nincsenek benne): 8 fö ideiglenesen elhelyezett, 5 fö nevelésbe vételi eljárással érintett, 17 fő nevelésbe vett gyermek esetében. A mintába tehát ez a harminc fö került be, akiknek nemek szerinti megoszlása a következő: 17 fiú és 13 lány.

A 30 eset vezető tünet szerinti megoszlása a következőképpen alakul. Disszociális: 13 fö, pszichés: 17 fö, pszichoaktív szerhasználó: 0 fö.

Megjegyzendő, hogy ezek vezető tünetek, és az esetek többségében tisztán nem jelennek meg. A vezető tünet az a tünet, amely az adott gyermeknél hangsúlyosabb, vagy a gyermek ilyen irányban veszélyeztetett. Az adekvát segítségnyújtást, és a gyermek elhelyezését határozzák meg. A speciális szükségletü gyermekek/fiatalok problémái gyakran összetettek, tüneteik mozgalmasak, gyakran változnak ezért a terápiás profilok kialakításában a vezető problémát kell meghatározónak tekinteni. (Speciális Ellátás Módszertani Munkacsoport, 2011)

A vizsgálatot a következőképpen végeztem el:

A szakvélemények feldolgozása során kigyüjtöttem az előforduló tüneteket, valamint a részvizsgálatok tanulmányozása során megkerestem mindazon háttértényezőket, amelyek az adott gyermek életútjára hatással lehettek. A tünetek és háttértényezők értékelésénél, azok előfordulási gyakoriságát tudtam alapul venni, annak ellenére, hogy 30 fös mintán dolgoztam. Véleményem szerint így kaphatunk arról képet, hogy melyek a típusos tünetek, valamint a háttértényezők szerepére is így lehet következtetni a speciális szükséglet megjelenése szempontjából az adott évben Hajdú-Bihar megyében.

A tüneteket és a háttértényezőket összesítettem és csoportosítottam.

Tünetek: Lopás; iskolai teljesitményzavar; iskolai hiányzás; engedély nélküli távollét; auto/hetero agresszió; szexuális túlfütöttség; betörés; garázdaságrongálás; gyógyszer elutasitása; kábitószer/gyógyszer/szerves oldószerfogyasztás; impulzivitás; sodorhatóság; öntörvényüség; alkoholfogyasztás; opponáló magatartás; gyújtogatás; játékszenvedély; prostitúció; suicid kisérlet; rablás; állatkínzás 
Háttértényezők:

A háttértényezőket három részre tudtam osztani. A családi háttértényezők a gyermek családjában, közvetlen környezetében (szocializációs színterek) meghatározó történések. A pszichológiai háttértényezők a gyermek személyiségfejlödését meghatározó tényezők. Rendszertényezőknek neveztem el a harmadik kategóriát, utalva a gyermeket segítő-támogató rendszerre. Ennek esetleges diszfunkciója a segítő-támogató funkciót kérdőjelezi meg. Két részre osztottam ezt a kategóriát. Az első kategória a gyermek mozgatására, környezetének változtatására, állandóságának figyelmen kívül hagyására fókuszál. A másik kategória az időben meg nem kapott segítségnyújtás, annak elmaradásának jelentőségére hívja föl a figyelmet.

Családi háttértényezők: Szülők válása, különélése; új élettárssal való konfliktus; szülö lojalitása az új élettárs felé; a szülö kéri a családból történö kiemelést; a szülö nem tart kapcsolatot; szülői elhanyagolás; negatív családi-környezeti minta; családban elszenvedett fizikai bántalmazás; szülö alkoholizálása, szenvedélybetegsége; szülő pszichiátriai betegsége; nevelési eszköztár hiányossága; szülői suicidum tanúja; teljesitményorientált nevelés

Pszichológiai háttértényezők: Szülővel való ambivalens kapcsolat; elsődleges kötödés sérülése; feldolgozatlan gyász, veszteség; szocializációs hiányosságok; beilleszkedési alkalmazkodási zavar

Rendszertényezők

-Változások a gyermek elhelyezésében: Többszörös gondozási hely változtatás; többszörös családon belüli elhelyezés; többszörös iskolaváltás.

-Adekvát segítségnyújtás hiánya: Nem részesült adekvát segitségnyújtásban; családterápia meghiúsulása; pszichoterápia meghiúsulása; rendszerabúzus.

\section{A speciális szükségletü gyermekek tüneteinek vizsgálata}

A tüneteket a 2011. évben speciális szükségletüvé nyilvánított gyermekek szakvéleményeiben előforduló gyakoriságuk alapján értékeltem. Azt néztem meg, hogy a harminc szakvéleményből az egyes tüneteknek milyen az előfordulási gyakorisága. Jelzés értékünek tekintettem, ha az esetek harmadánál előfordul az adott tünet. 
A legnagyobb gyakorisággal előforduló tünet az engedély nélküli távollét volt. 30 esetből 24-szer fordult ez elő. Az engedély nélküli távollét alatt kell érteni a csavargást, szülői engedély hiányában történő távollétet, valamint a gondozási helyről történő engedély nélküli eltávozást, a szökést. Azt látjuk, hogy az esetek döntő többségében előfordul, hogy a gyermek nem tartózkodik folyamatosan a gondozási helyén. Amennyiben még otthon nevelkedik gondot jelent az, hogy huzamosabb ideig a szülő/törvényes képviselő nem rendelkezik információval arra vonatkozóan, hogy hol tartózkodik napközben, illetve éjszaka a gyermek. Fontosnak tartom kiemelni, hogy ez a tünet, illetve a tünetek önmagukban, nem kizárólagos prediktorai az esetleges speciális ellátási igény megállapításának. Az engedély nélküli távollét hátterében számos tényező állhat, amelyet célzott segítségnyújtással kezelhetünk.

A másik kirívó gyakorisággal előforduló tünet az auto-/heteroagresszió volt. 30 esetből 23 volt az előfordulási gyakorisága. Ide kapcsolhatóak lettek volna a bünügyi irányba elmozduló tünetek (betörés, garázdaság-rongálás, gyújtogatás, rablás, állatkínzás), valamint az elsősorban pszichés labilitás talaján előforduló a vizsgálatom által nevesített autoagresszív megnyilvánulások is (kábítószer fogyasztás, alkoholfogyasztás, suicid kísérlet), azonban ezeket a tüneteket én mégis külön kezeltem. Ennek oka, hogy a tünetek egy része már büntetőjogi kategória, és kezelésére megvannak a rendszer sajátos eszközei, másik része pedig szintén célzott segítségnyújtással kezelhető. Véleményem szerint ezek gyakorisága nagy előrejelző jelentőséggel bírhat. Auto/hetero agresszió alatt elsősorban a fizikai agressziót értettem, amely egyrészt a gyermek környezete, másrészt önmaga ellen irányul. Gyakori esetek voltak, hogy a gyermek a gondozási helyén megveri a fiatalabb gyermekeket, illetve kárt tesz fizikai környezetében (berendezési tárgyak). Előfordult felnőttekkel szemben tanúsított fizikai agresszió is. Ezek közül gyakoribb volt az iskolai pedagógussal, valamint a gondozási hely nevelöjével szemben tanúsított agresszív megnyilvánulás. Ritkább volt a szülővel/törvényes képviselővel szembeni fellépés. Előfordult iskolában a társakkal szemben megnyilvánuló fizikai agresszió is. Önmagában való károkozás a legtöbb esetben a saját alkar megvagdalásában nyilvánult meg, azonban előfordult olyan eset is, amikor a gyermek a fejét a falba verte. Az kitünik, hogy az agresszió, mint tüneti kategória viszonyítható egyéb általam nevesített kategóriákkal. Érdekes lenne megvizsgálni, hogy azokban az esetekben, amikor előfordul iskolában megnyilvánuló agresszió, az az iskolai teljesítményzavarral mutat-e összefüggést. Az iskolai hiányzás is magas gyakorisággal előforduló tünet volt. Ez a kategória bizonyos szempontból rokonítható az engedély nélküli eltávozással, mégis külön kategóriaként kezeltem. Ennek oka, hogy mögötte ugyan munkálkodhatnak az előzővel azonos háttértényezők, de mégis mivel iskolai környezethez kapcsolódik, iskolaspecifikus háttérmechanizmusokkal egészülhet ki. Akár állhat a hátteré- 
ben iskolai teljesítményzavar is, a nem megfelelő iskola típus stb. Az látható, hogy 30 esetből 16 esetben fordult elő iskolai hiányzás. Ez legtöbbször igazolatlan hiányzásokban nyilvánult meg, de előfordultak óráról való késések is. Megjegyzendő, hogy a két eset minden esetben együtt járt, pusztán óráról való késések nem jelentek meg. Az is megjegyzendő, hogy óvatosan kell bánni ezzel az eredménnyel, hiszen ebbe a kategóriába soroltam a magántanulói jogviszonyban álló felkészítést és osztályozó vizsgát elmulasztó gyermekek esetét is. Ennek az az oka, hogy anamnézisükben az ő esetükben is legtöbbször (de nem minden esetben) iskolai hiányzás vezetett magántanulóvá nyilvánításukhoz.

A lopás előfordulásának gyakorisága is igen magas. 30 esetből 15 esetben fordult elő. Lopás alatt valamilyen tárgy engedély nélküli fizikai agressziótól mentes eltulajdonítását értem. Ha már előfordult agresszió, akkor azt külön kategóriaként kezeltem. Fontos megjegyezni, hogy ennek a tünetnek is van bünügyekkel kapcsolatos vetülete. Egyrészt ez is büntetőjogi kategória, másrészt indulhat hatósági eljárás is lopási ügyben. Hangsúlyoznám ennél a kategóriánál is, hogy a lopás önmagában nem határozza meg a speciális ellátási igényt, ugyanakkor ez a magas szám mégis elgondolkoztató a tekintetben, hogy milyen háttértényezők határozzák meg azt a tüneti együttállást, ahol ennek a tünetnek a gyakorisága igen magas.

Gyakran fordult elő a tünetek közül az opponáló magatartás is. 30 esetből 10 esetben jelent meg ez. Ez alatt valamilyen tekintély személy elleni engedetlenséget értek. Ennek megnyilvánulásai: nem fogad szót a gyermek szülőjének/ törvényes képviselőjének/ nevelöjének, verbális agresszióval él ezen személyek felé, gyakori a provokáció. Amennyiben ez túlment a verbális agresszión, azt külön kategóriaként kezeltem. Egyértelmüen látszik a kapcsolat az agreszszió tünettel. Az opponálás megjelenhet iskolában is, pedagógusokkal szemben elsősorban, így összefügghet akár az iskolai hiányzással, akár egy esetleges iskolai teljesítményzavarral. Ezen tünetek közös gyökere valószínüsíthető.

Kábitószer/gyógyszer/szerves oldószer fogyasztás szintén 10 esetben fordult elö. Ez igen magas gyakoriság annak a tükrében is, hogy 2011. évben pszichoaktív szerhasználat vezető tünettel nem nyilvánított a Szakértői Bizottság egy fö́t sem speciális szükségletüvé. Ennek ellenére a pszichoaktív szerhasználat magas gyakorisággal van jelen a tünetek között. Ennek az az oka, hogy a bizottság más tünetek jelenlétében látja a vezető problémát, a problémaprofil felállításakor elsősorban nem a szerhasználatnak van kitüntetett jelentősége. A szerhasználat hátterében pszichés vagy disszociális mechanizmusokat feltételeznek, ezért a terápiás profil kialakításában az adott vezető probléma tekinthető meghatározónak. 


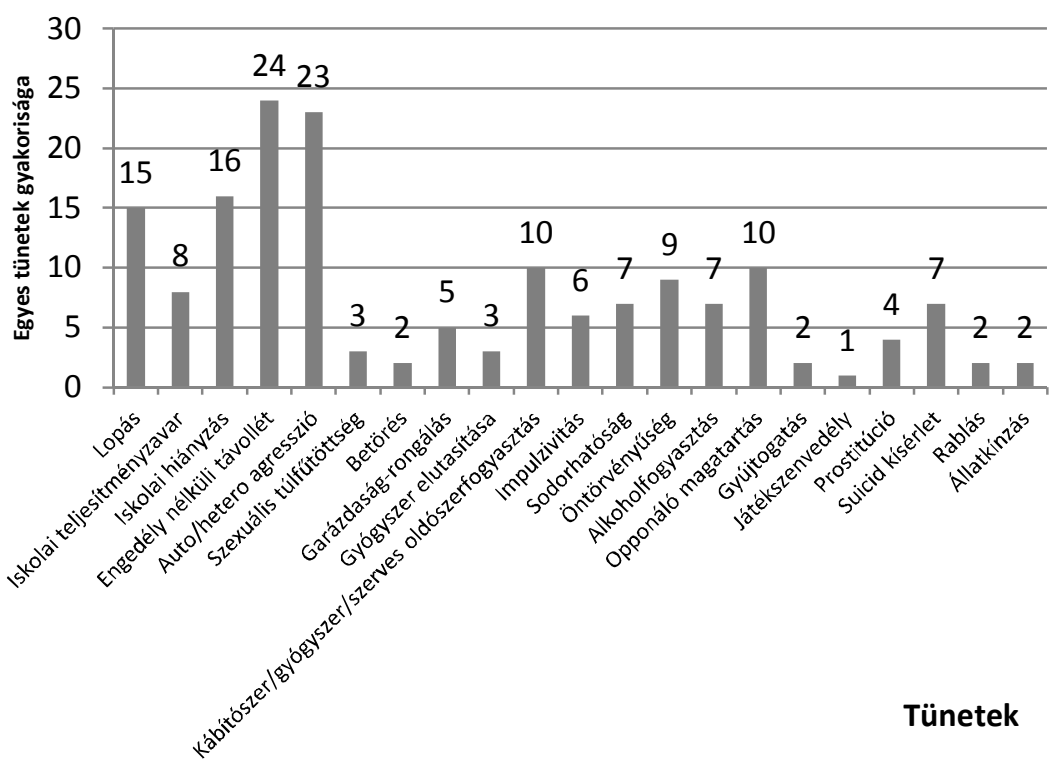

1. ábra: Tünetek egymáshoz viszonyított gyakorisága

Az 1. ábrán látható, hogy a leggyakrabban előforduló tünetek a fentebb ismertetett tünetek voltak. Az engedély nélküli eltávozások, az auto/hetroagresszió tünetek hangsúlyossága vitathatatlan, ugyanakkor a lopás, iskolai hiányzás tünetek megjelenése is igen gyakori. Az opponáló magatartás és a kábítószer fogyasztás gyakoriságától nem sokban marad le az öntörvényüség, az iskolai teljesítményzavar, a sodorhatóság, az alkohol fogyasztás és a suicid kísérlet sem.

Az öntörvényüség 9 esetben fordult elő a 30 szakvéleményből. A nehezen irányíthatóság, a saját út járása, tanácsok és legfőképpen a szabályok figyelmen kívül hagyása az, amely meghatározza ezt a tünetet. Az öntörvényü viselkedés a legtöbbször a házirend be nem tartásával nyilvánult meg, összefüggésbe hozható az engedély nélküli eltávozásokkal, az opponáló magatartással, de terelődhet bünügyi irányba, ezeket az eseteket külön kezeltem. Megjegyzendö, hogy statisztikailag szinte jelentéktelen a különbség az opponáló magatartás és az öntörvényű viselkedés tünete között, amely azok együttjárását erősen feltételezi, így valószínüsíthető hasonló háttértényezők szerepe ezen tünetek megjelenésében. 
Az iskolai teljesitményzavar 8 esetben fordult elö. Azt gondolom igen magas gyakoriság ez is, hathat az iskolai hiányzás előfordulására is. A magántanulóvá nyilvánítások hátterében ez a másik tényező (az iskolai hiányzások mellett), így valószínüsíthető, hogy ezen tünetek mögött hasonló háttérmechanizmusok munkálkodhatnak. Az iskolai teljesítményzavar a gyermekben frusztrációt vált ki, így kérdéses ez a feszültség milyen módon vezetődik le. Ezért úgy gondolom összefüggésbe hozható az agresszió, opponáló magatartás gyökereivel is.

A sodorhatóság 7 esetben jelent meg, mint tünet. A környezet csábító ingereire történő szelektálatlan érzékenység gyakran viszi a gyermeket akár disszociális, akár pszichés, akár szerhasználó feldolgozási módok felé. Ezért kapcsolatba hozható a bünelkövetői irányultságot mutató tünetekkel (betörés, rablás, prostitúció), akár a kábítószer használattal, de akár autoagresszív tünetek megjelenésével is (suicid kísérlet), ezért hátterében hasonló gyökerek feltételezhetőek.

Az alkoholfogyasztás is 7 esetben fordult elö. Alkoholfogyasztásnál csak azokat az eseteket gyüjtöttem össze, ahol az alkohol fogyasztása rendszerré, szenvedéllyé vált. Ami miatt mégis külön választottam a pszichoaktív szerhasználattól, az az alkoholfogyasztás legális volta. Jelzésértékünek tekinteném, hogy a kábítószer fogyasztás gyakran együtt járt az alkoholfogyasztással. Önmagában is megjelent ugyan, de elhanyagolható gyakorisággal. Hátterükben hasonló mechanizmusok munkálkodhatnak.

A suicid kisérlet 30 esetböl 7 szakvéleményben fordult elö. Feltételezhető együttjárása az agresszió tünettel, azon belül az autoagresszív tünetekkel, illetve egyéb általam nevesített autoagresszív megnyilvánulásokkal: a kábítószer, és alkohol fogyasztással, ezért hátterében hasonló gyökerek feltételezhetőek.

Az impulzivitás 6 esetben jelent meg, minden esetben előfordultak már korábban indulatkezelési nehézségek. A hyperkinetikus magatartászavar mind a hat esetben szerepelt a gyermekpszichiátriai anamnézisben. A lobbanékonyság, indulatosság, és a hyperkinézis az, amely meghatározza ezt a tünetet. Együtt járása az agresszióval, öntörvényüséggel, és a bünügyi jellegü tünetekkel feltételezhetô.

Garázdaság-rongálás 5 esetben fordult elő. A heteroagressziótól azért választottam külön ezt a tünetet, mert ezekben az esetekben már eljárás is indult a gyermekkel szemben. Ugyanakkor egyértelmü együtt járása az agresszió tünettel. Ugyanez a helyzet a betörés (2 eset), a rablás (2 eset), állatkínzás ( 2 eset), gyújtogatás (2 eset) tünetekkel. Nagy jelentősége lehet még a sodorhatóságnak is.

A prostitúció 4 esetben fordult elő. Feltételezhető a sodorhatósággal való együtt járás, hiszen a stabil kötődésre való vágya a gyermeknek az, amely bele kényszeríti ôt a prostitúcióba. 
A szexuális túlfütöttség és a gyógyszer elutasitása 3-3 esetben fordult elő. Míg az előbbi inkább az impulzivitáshoz, sodorhatósághoz és az agresszióhoz köthető, az utóbbi inkább az autoagresszív megnyilvánulások talajáról táplálkozik. Játékszenvedély 1 esetben fordult elő. Hátterében a kábítószer és alkoholfogyasztáshoz hasonló mechanizmusok munkálkodhatnak.

\section{Háttértényezők vizsgálata}

Hasonlóképpen a tünetek értékeléséhez, a háttértényezők esetében is az előfordulási gyakoriságokat vizsgáltam. A szakvélemények feldolgozása során kigyüjtöttem azokat a tényezőket, amelyek az adott tünet, tünetcsoport kialakulásához vezethet. Így kaptam a háttértényezőkből egy listát, amelyet kategóriákba rendszereztem. Ahogy korábban már említettem alapvetően három típust lehetett elkülöníteni: családi háttértényezők, pszichológiai háttértényezők, rendszertényezők.

Vizsgáltam a háttértényezők csoportjának egymáshoz viszonyított gyakoriságát, és az egyes háttértényezők egymáshoz viszonyított gyakoriságát is. Ezekből az eredményekből véleményem szerint arra lehet következtetni, hogy az adott évben a speciális szükséglet kialakulásában milyen háttérmechanizmusok játszhatnak szerepet.

A családi háttértényezők a gyermek családjában, közvetlen környezetében (szocializációs színterek) meghatározó történések. Az látszik, hogy ezek a háttértényezők rokoníthatóak a gyermekvédelmi szakellátásba kerülés okaival, a nevelésbe kerülö gyermekek kríziseivel is. Megjegyzendő, hogy ezek a kategóriák a 2011-es eseteket tükrözik. Több év vizsgálata alapján akár több háttértényező előfordulása is valószínüsíthető lenne, és ez igaz lehet akár a pszichológiai és a rendszertényezőkre is. Ezért ennek eredményei csak is az adott évre nézve értékelhetőek.

A családi háttértényezők közül a szülői elhanyagolásnak van a legmagasabb gyakorisága. A 30 szakvéleményből 15 esetben fordult ez elő. Szülői elhanyagolás alatt a gyermek gondozásának, nevelésének elmulasztását értem. Ebbe beletartozik a fizikai, érzelmi elhanyagolás, illetve a gyermek szükségleteinek figyelmen kívül hagyása: oktatás, egészségügyi ellátás. Ez a magas szám nem meglepő, hiszen a szakellátásba kerülés okai közül is jelentős szerepet kap az elhanyagolás. Az ideiglenes hatályú elhelyezéssel és nevelésbe vételi eljárással érintett esetekben ennek a kategóriának nagyobb jelentősége volt, mint a már nevelésbe vett gyermekek esetében, hiszen a gyermek éppen ezen eljárás keretében lett kiemelve a családból. A többi gyermek anamnézisében is gyakran jelent meg az elhanyagolás. A szülői elhanyagolás talaján számos tünet megjelenhet, gyakran kombinálódva pszichológiai és egyéb háttértényezővel: lopás, iskolai hiányzás, alkohol-kábítószer fogyasztás, sodorhatóság. 
A negatív családi-környezeti minta gyakorisága is igen magas volt, 14 esetben jelent ez meg. Negatív minta alatt értem, amikor a gyermek családja, rokoni kapcsolatai vagy kortárs kapcsolatai a gyermek szocializációját nem segítik, vagy olyan irányba terelik, amely a gyermek környezetéhez való alkalmazkodását nem segítik elő. Előfordult, hogy a gyermek családja bünelkövető életmódot fojtatott, valamelyik családtagja börtönbüntetését töltötte, vagy sodorhatósága következtében a gondozási helyen tartózkodó társai vonták be a gyermeket különböző büncselekmények elkövetésébe. A gyermek szocializációja során ezeket a negatív mintákat belsővé teheti, amely a problémamegoldó eszközeit meghatározhatja. A negatív minta talaján pedig rengeteg tünet kialakulhat: auto/heteroagresszió, különböző bünelkövetői viselkedésformák (rablás, garázdaság), de a lopás egyik háttere is lehet ez.

13 esetben fordult az elö, hogy a szülö kérte gyermeke családból történö kiemelését. Ennek pszichológiai hatása úgy gondolom vitathatatlan. Ennek a háttértényezőnek ezt a szegmensét akartam megragadni, kevésbé azt, milyen motiváció állt a szülői döntés hátterében. Mind a 13 esetben szükség volt a gyermek valamilyen pszichés vezetésére, amely miatt úgy gondolom, hogy egyéb más háttértényező hatása mellett a szülő ez irányú kérése is olyan folyamatokat indíthat el a gyermekben, amely a későbbiekben a speciális tünetképződést elősegíti.

Felmerül az is, hogy ezek a háttértényezők hatnak -e egymásra. A tüneteket nem lehet egy háttértényezőre visszavezetni. Egyes háttértényezők együtt járása határozhat meg egy adott tünet, illetve tünet együttes megjelenését. Ezért úgy gondolom, hogy mindenképpen kapcsolatba hozható a pszichológiai tényezőkkel.

Hasonló lehet az eset akkor is, amikor a szülö nem tart kapcsolatot a gyermekkel. Ezekben az esetekben is tapasztalható volt, hogy a gyermek pszichés vezetésre szorult. Két esetben az is előfordult, hogy a kapcsolat megszakadása után a gyermek rosszabb állapotba került, pszichoterápiába vonását újra meg kellett kezdeni. Érdekes lehet, hogy a szülő kéri a szakellátásba kerüléshez hasonlóan, 13 esetben fordult elö a kapcsolattartás elmulasztása is. Ennek hátterében nyilván számos tényező állhat, viszont az látszik, hogy jelentős számban fordult elő ez az anamnézisekben. Pszichológiai háttértényezőkkel (szülővel való ambivalens kapcsolat) való kapcsolata vitathatatlan.

A nevelési eszköztár hiányossága 30 esetből 12 esetben fordult elő. Ez a háttértényező rokonítható a szülői elhanyagolással, a szülő kéri a családból történő kiemeléssel, de akár a teljesítmény orientált neveléssel is. A hangsúlyt ennél a kategóriánál arra fektetném, amikor a szülö/törvényes képviselő képességei folytán eszköztelen a gyermek nevelésében. Az eszköztelenségének pedig a gyermeknél számos következménye lehet: iskolai hiányzás, engedély nélküli távollét, bünügyi jellegü tünetek. Ez pedig oda vezethet, hogy a szülő kéri a családból történő kiemelést, amelynek esetleges következményeiről fentebb tettem már említést. 


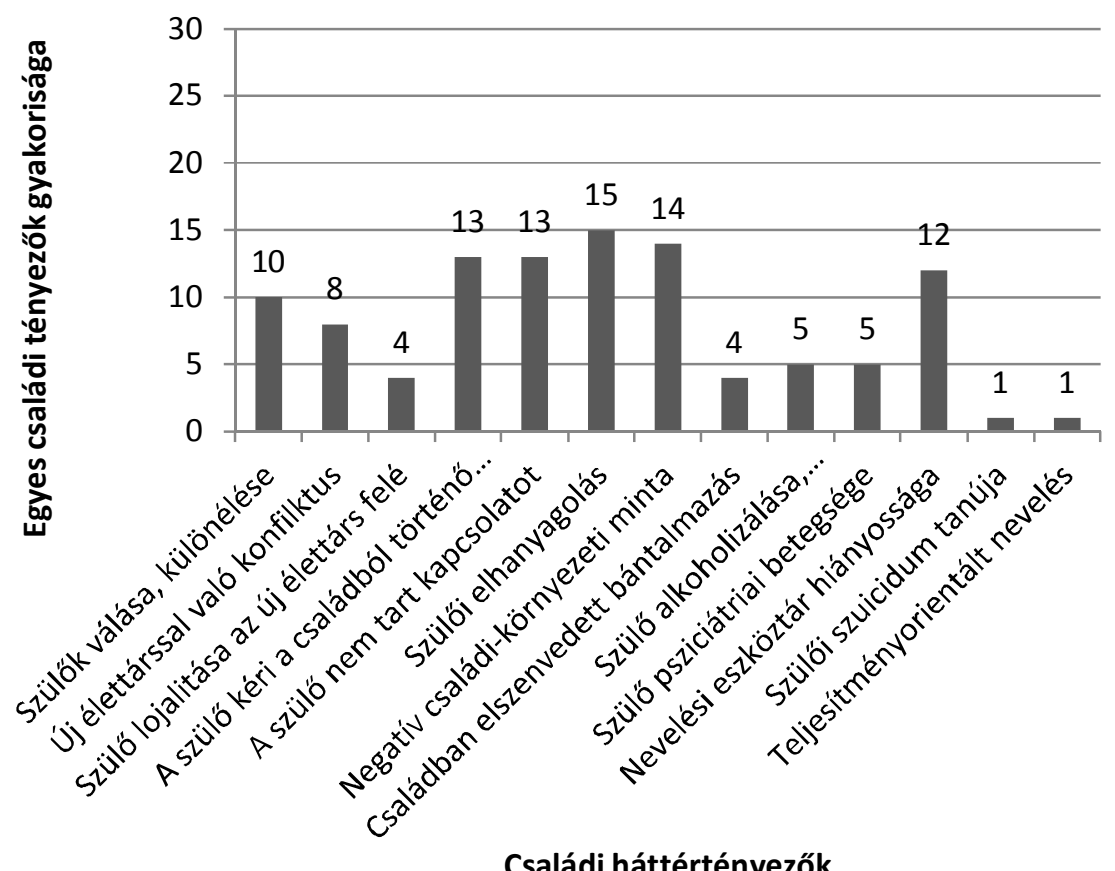

2. ábra Családi háttértényezők egymáshoz viszonyított gyakorisága

A 2.ábrán látható, hogy leggyakrabban előforduló családi háttértényezők a szülői elhanyagolás, a szülő kéri a családból történő kiemelést, a szülő nem tart kapcsolatot a gyermekkel, a negatív családi-környezeti minta, és a nevelési eszköztár hiányossága. Ezeknek a háttértényezőknek az egymásra hatása erősen valószínüsíthető. A szülői elhanyagolás és a nevelési eszköztár hiányossága összefüggést mutathat, ugyanakkor elmondható ez a kapcsolattartás hiányára és a családból történő kiemelésre is.

A szülők válása, külön élése 10 esetben fordult elő. Pszichológiai háttértényezőkkel való kapcsolata erősen valószínüsíthető. A feldolgozatlan veszteségélmény, a szülővel való ambivalens kapcsolat és az elsődleges kötődés sérülése párhuzamba állítható ezzel a háttértényezővel. Ezen tényezők kapcsolata válto- 
zatos tünetek megjelenését idézheti elő (lopás, agresszió, szexuális túlfütöttség, sodorhatóság, kábítószer fogyasztás, suicid kísérlet).

8 esetben fordult elő az új élettárssal való konfliktus Együttjárása szembe tünő a szülők válása, különélése háttértényezővel. Kapcsolata más pszichológiai tényezőkkel hasonlóképpen a szülők válásához, erősen valószínüsíthető. Ezen belül a szülővel való ambivalens kapcsolat előtérbe kerül, ezáltal kapcsolatba hozható még a szülő kérésére a családból történő kiemelésre, és a szülői kapcsolattartás hiányára is.

A szülö alkoholizálása, szenvedélybetegsége és a szülő pszichiátriai betegsége 5-5 esetben fordult elö. A családban elszenvedett fizikai bántalmazás pedig 4 esetben. Ezen háttértényezők párhuzamba állítása lehetséges. A szülői elhanyagolással is mutathat kapcsolatot. Szocializációs hiányosságokkal, negatív családi-környezeti mintával illetve egyéb pszichológiai háttértényezőkkel (szülővel ambivalens kapcsolat) kiegészülve előre jelezheti a speciális tünetképzödést.

A szülö lojalitása az új élettárs felé szintén 4 esetben fordult elö. Ez a háttértényező együtt jár a szülő válása, különélésével, illetve az új élettárssal való konfliktussal. A szülővel való ambivalens kapcsolattal, feldolgozatlan veszteségélménnyel kiegészülve számos általam nevesített tünet hátterében állhat.

A szülöi suicidum tanúja és a teljesitményorientált nevelés 1-1 esetben fordult elő. Az előbbi traumatikus eseménynek és az utóbbi nevelési módszernek egyértelmü pszichológiai háttértényezős vonzatai vannak. Ugyanakkor ezen háttértényezők előfordulási gyakorisága alacsony.

A pszichológiai háttértényezők a gyermek személyiségfejlődését meghatározó tényezők. Amikor összesítettem a gyakoriságokat azzal találkoztam, hogy ugyan kevesebb pszichológiai háttértényezőt tudtam összegyüjteni, mint családit, ugyanakkor itt magasabb gyakoriságok jelentkeztek. Az látszik, hogy a családi nevelkedés kapcsán számos tényező hat a gyermekre, azok előfordulási gyakorisága erősen megoszlik a csoporton belül. Az is látszik, hogy kevesebb pszichológiai tényező hat a gyermekre, de a csoporton belül ezek a tényezők magasabb gyakorisággal vannak jelen. Az eredmények értékelésénél ezt figyelembe kellett vennem.

A 3. ábráról leolvasható, hogy 30 esetből 18 esetben jelent meg a feldolgozatlan gyász, veszteség. Nem választottam külön kategóriába a szülő halálát és a veszteséget. A magas előfordulási gyakoriság azt jelzi, hogy ennek a háttértényezönek a szerepe a speciális szükséglet kialakulásában erősen valószínűsíthető. 


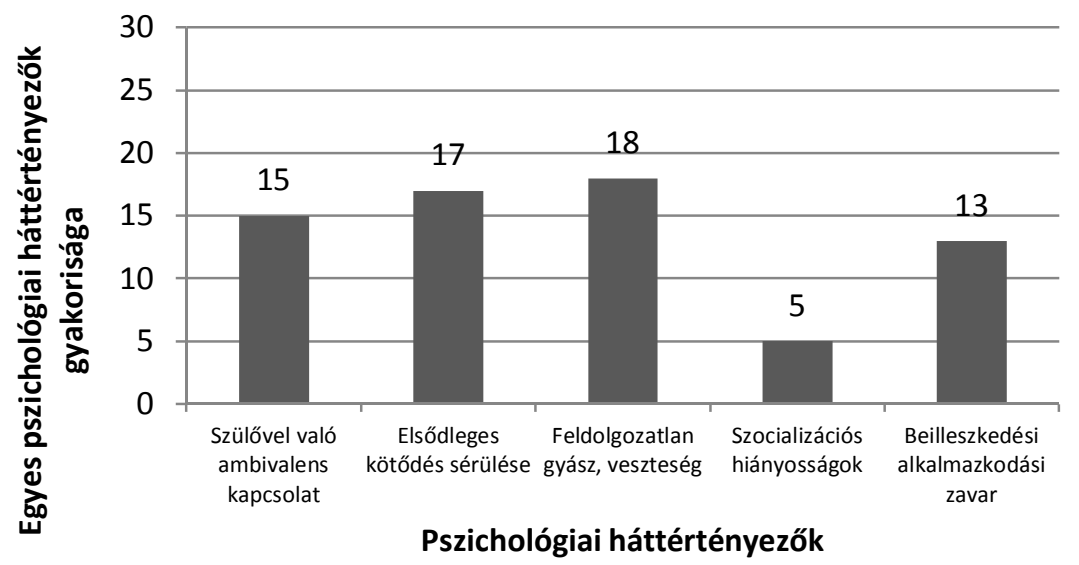

3. ábra: Pszichológiai háttértényezők egymáshoz viszonyított gyakorisága

Egyes családi háttértényezőkkel való párhuzamba állításáról már tettem említést (szülők válása, szülő kéri a családból történő kiemelést, a szülő nem tart kapcsolatot, szülői suicidum tanúja). A feldolgozatlan gyász számos tünet hátterében állhat: iskolai teljesítményzavar, auto/heteroagresszió, kábítószer fogyasztás, alkohol fogyasztás, suicid kísérlet. Hangsúlyoznám, hogy ezeknek a tüneteknek a megjelenését nem lehet csupán erre a háttértényezőre visszavezetni, számos mechanizmus dolgozik a háttérben.

Az elsödleges kötödés sérülése 17 esetben fordult elö. Ez a magas szám azt jelzi, hogy az esetek nagy részében kötődési probléma is jelen van a háttérben. Bizonyos fokig rokonítható a veszteségélménnyel és a szülővel való ambivalens kapcsolattal is. A kötődés sérülése számos pszichológiai és gyermekpszichiátriai problémát határoz meg, és hatással van a gyermek alkalmazkodási képességére, szocializációjára, a társadalmi normákhoz való viszonyára. Az elsődleges kötődés sérülése szerepet játszik a következő tünetek kialakulásában: lopás, engedély nélküli távollét, szexuális túlfütöttség, sodorhatóság, öntörvényüség, opponáló magatartás, bünügyi jellegü tünetek.

A szülővel való ambivalens kapcsolat az esetek felében fordult elő. Az ambivalens kapcsolat együtt járhat a kötődés sérülésével, vagy feldolgozatlan veszte 
séggel is. A családi háttértényezők többségével összefüggésbe hozható (szülői elhanyagolás, a szülő nem tart kapcsolatot...). Amennyiben a tünetek alapján a szakember megállapítja, hogy a háttérben ambivalens kapcsolat áll, ebben az esetben családterápia igénybevételére tesz javaslatot. Ez önmagában is ambivalencia, hiszen ha a gyermek speciális szükségletü, adekvát speciális ellátást kell, hogy kapjon. Ezt speciális gyermekotthonban, vagy gyermekotthon speciális csoportjában kapja meg, tehát gondozási helyen nevelkedik a gyermek. A családterápia lefojtatása tehát már csak azért is nehezített, mert nem otthon nevelkedik a gyermek. Ez elöre vetíti a rendszertényezők jelentőségét a szükséglet kialakulása szempontjából.

13 esetben fordult elő diagnosztizált beilleszkedési, alkalmazkodási zavar. Gyanítható azonban, hogy ez a szám akár magasabb is lehet, hiszen a diagnosztizált esetként való előfordulást vettem csak alapul. A szám ebben az esetben is igen magas. A beilleszkedési problémát és az elsődleges kötődés sérülését párhuzamba lehet állítani. Hozzájuk hasonló tünetek kapcsolódhatnak.

Diagnosztizált szocializációs hiányosság 5 esetben fordult elő. Hasonlóképpen a beilleszkedési zavarhoz, ez a szám is magasabb lehet, hiszen a diagnózisban szereplő szocializációs hiányosságot vettem alapul.

A gyakoriságokból arra tudok következtetni, hogy a pszichológiai háttértényezők egymással szoros kapcsolatban állnak. A gyakoriságok eloszlása is azt mutatja, hogy erősebb párhuzam van ezen háttértényezők között, mint a családi háttértényezők között. Részben ez azért lehet, mert jóval kevesebb pszichológiai háttértényezőt sikerült azonosítani, másrészről az egyes pszichológiai tényezőket igen nehéz elválasztani egymástól, hatnak egymásra és a magas gyakoriságok miatt jelentős szerepük lehet azon tünetek kialakításában, amelyek később a speciális szükséglet megállapítását meghatározzák.

Rendszertényezők alatt a gyermeket segítö-támogató rendszereket értem. A segítő-támogató funkció zavarára helyeztem a hangsúlyt, hiszen ha diszfunkció áll fenn, az hozzájárulhat a későbbi speciális tünetképződéshez. Ennek a háttértényezőnek két összetevőjét azonosítottam. Az első a gyermek mozgatására, környezetének változtatására, állandóságának figyelmen kívül hagyására fókuszál. A másik az időben meg nem kapott segítségnyújtás, annak elmaradásának jelentőségére hívja föl a figyelmet. Ezen kategóriákon belül természetesen nevesítve lettek az egyes háttértényezők.

A rendszertényezők első csoportja: a változások a gyermek életében (4. ábra). Három háttértényezőt sikerült ebben a kategóriában azonosítani. 


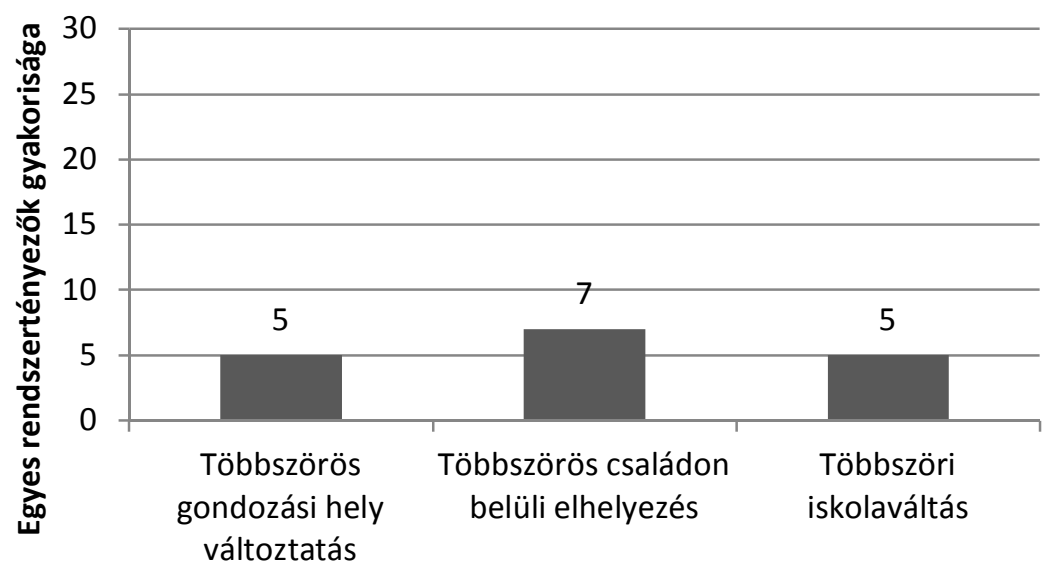

Rendszetényezők: változás a gyermek életében

4. ábra: Rendszertényezők: változások egymáshoz viszonyított gyakorisága

A többszörös családon belüli elhelyezés 7 esetben fordult elö. A gyermek legfontosabb természetes erőforrása, támogató rendszere a szülői háztartás, szélesen értelmezve a család, rokonság a szubszidiaritás elvét figyelembe véve. Amenynyiben a szülői háztartás nem tudja segítő funkcióját ellátni, ezt a funkciót a tágabb család is átveheti. Ezekben az esetekben többször előforduló elhelyezéseket gyüjtöttem össze. Előfordult, hogy gyermek elhelyezési per során többször máshoz helyezték el a gyermeket (másik szülő, nagyszülö). Leggyakrabban a családba fogadás által gyámhoz, majd onnan vissza a szülöhöz történt az elhelyezés. Ezeket az elhelyezéseket már akcidentális krízisek előzték meg, így erős a párhuzam a családi háttértényezők többségével. A gyermek elhelyezése már maga is krízis, a többszörös elhelyezés a gyermek személyiség fejlődésére rányomja a bélyegét. A gyermek veszteséget él át, be kell illeszkednie, a szülővel ambivalens érzései támadnak, ezért a pszichológiai háttértényezőkkel való kapcsolata vitathatatlan.

A többszörös gondozási hely változtatás, és a többszörös iskolaváltás 5-5 esetben fordult elő. A gondozási hely változtatás háttértényezőt akár lehetett volna a segítségnyújtás elmaradása kategóriába is sorolni, hiszen adekvát szakmai segítség hiánya vezet a legtöbb esetben a gyermek gondozási hely változtatásához. Mégis inkább a változások a gyermek életében kategóriába soroltam, mert elsősorban az állandóság biztosításának hiányára akartam a figyelmet fel- 
hívni. Fontosnak tartom azt is kiemelni, hogy a speciális szükséglet megállapítása a legtöbb esetben gondozási hely változtatással jár. Olyan gondozási helyre kerül a gyermek, ahol ezen szükségletét ki tudják elégíteni. Jelen helyzetben én nem ezekre az esetekre gondolok, hanem a szükséglet megállapításáig bekövetkező gondozási hely változtatásokra. Ezt a gyakoriságot annak tükrében is magasnak értékelem, hogy 13 esetben a gondozási hely változtatás szóba sem jöhetett (ideiglenes hatályú elhelyezéssel és nevelésbe vételi eljárással érintett gyermekek), mert a gyermek éppen akkor lett érintve gyermekvédelmi szakellátással. 17 nevelésbe vett gyermek esetéből fordult elő 5 esetben a gondozási hely változtatás. A gyermek tünetei hátterében ilyenkor családi, pszichológiai tényezők állnak, amelyek kiegészülhetnek a rendszertényezők diszfunkciójával. A többszörös iskolaváltás lehet az egyik háttere a sorozatos iskolai hiányzásoknak, a teljesítményzavaroknak, amelyhez kapcsolódnak a beilleszkedési zavarok, ezért kapcsolatba hozható a pszichológiai háttértényezőkkel is.

A rendszertényezők másik csoportja a segítségnyújtások elmaradása (5. ábra):

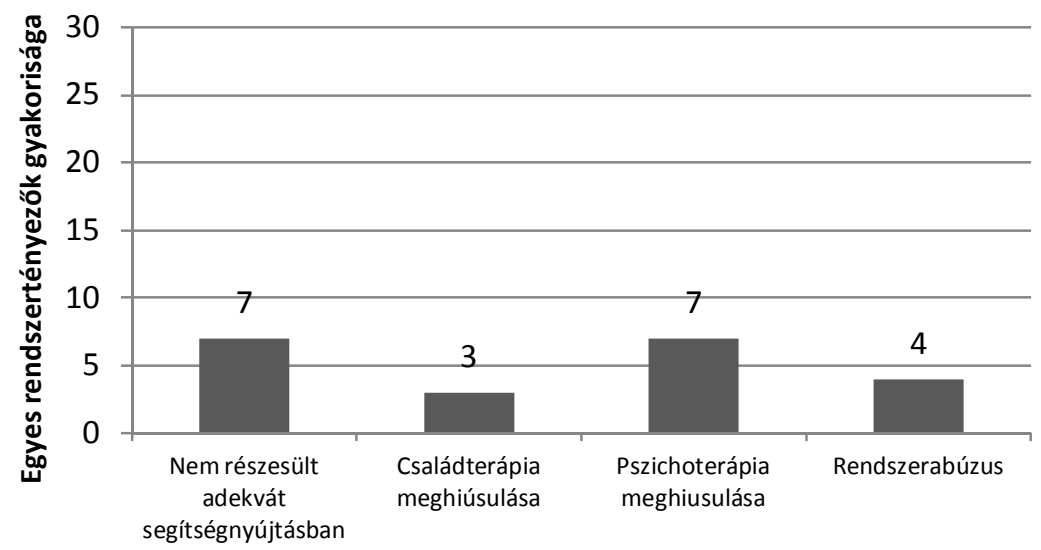

Rendszertényezők: adekvát segítségnyújtás hiánya

5. ábra: Rendszertényezők: segítségnyújtások elmaradásának egymáshoz viszonyított gyakorisága

A gyermek iratanyagából nyomon követhető az, hogy a család-gyermek életében mikor jelentkezett a probléma, ezt a problémát milyen módon kezelték. Az is kiderülhet, hogy a problémát ugyan jelezték, de nem lett megajánlva adekvát segítség- 
nyújtás, vagy nevesítve lett a segítség, de az nem valósult meg, mert nem volt a gyermek/család részéröl együttmüködés, vagy mert nem volt elérhető a nevesített szolgáltatás. A gyermek professzionális segítése számos területre kiterjed (egészségügy, oktatás, tehetséggondozás, gyermekpszichiátriai kezelés stb.), ugyanakkor a speciális szükséglet kialakulása szempontjából elsősorban a gyermek pszichés vezetését tartom fontosnak. Ezek közül a 2011-es évben a pszichoterápia és a családterápia esetében fordult elö, hogy nem tudott megvalósulni.

$\mathrm{Az}$ 5. ábráról leolvasható, hogy nem részesült adekvát segitségnyújtásban háttértényező 7 esetben fordult elö. Ilyenkor a segítségnyújtás meg sem lett ajánlva és feltételezhető, hogy megfelelő segítés mellett a probléma kezelhető lett volna. A probléma tovább gördül, és később már járulékos formában van jelen, tehát egyre nagyobb kihívást jelent ennek megoldása. A gondozási helyen előforduló hasonló eseteket ebbe a kategóriába nem soroltam bele, azt rendszerabúzusnak neveztem el. A tünetek hátterében lévő kezeletlen tényezők így hozzájárulhatnak a speciális szükséglet megjelenéséhez.

Rendszerabúzus 4 esetben fordult elö. Rendszerabúzus alatt értem, amikor a gondozási hely nem biztosítja az adekvát segítségnyújtást. A problémát észleli, de nem kér adekvát segítséget, vagy a meghatározott (pszichológus, Szakértői Bizottság által) segítségnyújtást nem biztosítja. Arra kell törekedni, hogy ez a gyakoriság minél alacsonyabb legyen, hiszen ez nem más, mint a gyermekvédelmi rendszer általi másodlagos veszélyeztetés. Ennek hátterében a gondozási hely személyi/tárgyi feltételeinek hiánya állt.

A pszichoterápia 7 esetben, a családterápia 3 esetben nem valósult meg. A gyermek vagy a szülő nem müködött együtt, ezért nem került rá sor. Ezek a segítségnyújtási formák az általam nevesített pszichológiai háttértényezők rendezésére irányulnak, ezáltal kezelve a gyermek tüneteit.

A rendszertényezők hatását nem szabad figyelmen kívül hagyni, hiszen befolyásolhatják a gyermek tüneteinek megjelenését, ezen tünetek eröteljesebb megnyilvánulását azáltal, hogy erősítik a gyermek akcidentális krízisét. Ez hat a családi és pszichológiai háttértényezőkre, majd változatos tünetek megjelenését segítheti elö.

Eddig az egyes háttértényezőket, és azok előfordulási gyakoriságát ismertettem. Ezeket a háttértényezőket, mint már említettem, csoportosítottam és megvizsgáltam egymáshoz viszonyított gyakoriságukat.

Az egyes kategóriákon belül összeadtam az előfordulási gyakoriságokat, így kaptam meg az adott kategória összes gyakoriságát az adott évben, amelyet a 6 . ábra szemlétet.

Az eredmények értékelésénél azt azonban figyelembe kell venni, hogy a családi háttértényezőkből lehetett a legtöbbet azonosítani. Amennyiben a rendszertényezőket együtt kezelem, akkor ez a háttértényező kategória követi a családit. 


\section{Háttértényezők gyakoriságának megoszlása}

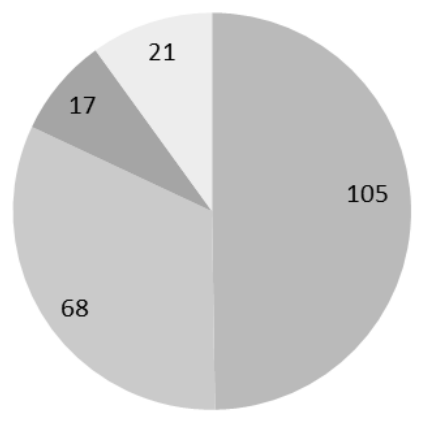

— Családi tényezők

- Pszichológiai tényezők

- Változások a gyermek

elhelyezésében

Adekvát segítségnyújtás hiánya

6. ábra: Háttértényezők gyakoriságának megoszlása

A legkevesebb háttértényező a pszichológiaiban volt. Az is látható, hogy itt magasabb gyakoriságok jelentkeztek. A családi tényezőkben is voltak magas gyakoriságok, azonban az egyes családi háttértényezők előfordulási gyakorisága erősen megoszlott a csoporton belül. Ugyan több rendszertényezöt azonosítottam, mint pszichológiait, de az egyes tényezők gyakorisága nem volt kiemelkedő mindamellett, hogy ezeket a gyakoriságokat én magasnak értékeltem. Ezek az eredmények a 2011-es évben történő speciális szükséglet megállapítása esetekben értékelendők.

A családi háttértényezők összes gyakorisága 105, a pszichológiai 68, a rendszertényezőké pedig 38. A háttértényezők csoportjai ekkora gyakorisággal felelősek azon tünetek kialakulásáért a 2011-es évben, amelyek a speciális szükséglet megállapításához vezetnek. Százalékos megoszlást nem készítettem, mivel a mintám nem érte el a 100 szakvéleményt. A családi tényezőknek kitüntetett szerepe van, mert a szocializáció által elsajátított belsővé tett problémamegoldó minták a családi nevelkedés kapcsán alakulnak ki. A pszichológiai tényezőknek pedig abban lehet jelentősége, hogy a belsővé tett minták által milyen személyes struktúrán keresztül fog megtörténni a tünetképződés (milyen irányt vesz disszociális, pszichés). Ennek hátterében pedig még ott van a rendszer diszfunkciója is. A pszichológiai háttértényezők is igen jelentős mértékben befolyásolják a tünetek kialakulását. Felmerülhet ok-okozati kérdés a családi és a pszichológiai háttértényezők között. A diszfunkcionális családi környezet áll a pszichológiai tényező hátterében, vagy fordítva, a családi háttértényező hátterében áll pszichológiai. Vizsgálatom során azt néztem, hogy tünetek hátterében milyen háttértényezők lehetnek, ezen tényezők okfejtésére nem vállalkoztam. A vizsgálat során azonban az kiderült, hogy ezeket az eseteket talán nem is ok-okozati viszonylat- 
ban kell értelmezni, hanem rendszer szemléletben. Világossá vált, hogy ezek a háttértényezők folyamatosan hatnak egymásra, elég csak a rendszertényezők jelentőségét megemlíteni. Ha nem kap a gyermek időben hatékony segítséget, a pszichológiai háttértényezők szerepe felértékelődik, amely kihathat a családi tényezőkre és végső soron az adott tünetre is. Konkrét példa erre, amikor a gyermek gyásza nincs feldolgozva. A család nem teszi lehetővé a folyamatot, külső segítséget nem kap. Az ennek talaján megjelenő tünet (agresszió, lopás, engedély nélküli távollét) hatással van a családi háttértényezőkre (új élettárssal való konfliktusos viszony, nevelési eszköztár hiányossága), amely az élő szülövel történő ambivalens érzelmi viszonyt alakíthat ki, és a fenti tünetek erősödését, újak megjelenését idézheti elő (kábítószer fogyasztás). Úgy gondolom a rendszer szemléletű megközelítés által értékelhetőek a kapott eredmények.

A rendszertényezők közel 38-as előfordulási gyakoriságát nagyon magas számnak tartom, ezen belül a segítségnyújtás hiánya miatti további járulékos problémák halmozódása komoly aggodalomra ad okot.

\section{Összegzés}

Vizsgálatom során kiderült, hogy a tünetek és háttértényezők kapcsolata rendszerszemléletü megközelítésmódot igényel. Világossá vált, hogy egyes tünetet, tünetcsoportot nem lehet kizárólagosan egy háttértényezőre, vagy háttértényezők csoportjára visszavezetni. Ahogy a háttértényezők hatnak a tünetre, a tünet is hat ezekre a tényezőkre és ez mind további mechanizmusokat indíthat el. A tünetek között is lehetett együtt járást feltételezni, hasonlóképpen müködött ez a háttértényezőknél is. A helyzetet még az is bonyolította, hogy ezek a tényezők, kategórián belül is hatottak egymásra, de kategórián kívüli együtt járásokra is lehetett következtetni.

Ez a rendszerszemléletü megközelítés azt követelné meg, hogy a gyermek terápiájában ne a tünet kezelésére helyezzék a hangsúlyt, hanem a háttérmechanizmusok mélyére nézve kellene a gyermek segítségnyújtását biztosítani. Az is világossá vált, hogy a szakellátásba kerülés krízisei és a speciális szükséglet háttértényezői között is szoros összefüggés van, már csak azért is, mert ezt a szükségletet szakellátással való érintettség kapcsán lehet megállapítani.

A családi háttértényezők kiemelt jelentősége is bebizonyosodott a vizsgálat során mindamellett, hogy a pszichológiai és rendszertényezőkkel való együttes viszonyulás rendszerében lehet csak értelmezni a tünetek megjelenését. A családi háttértényezők jelentőségének további vizsgálatát fontosnak tartanám. Érdemes lenne megvizsgálni több évre visszamenően, a családi háttértényezők gyakoriságát. Valószínüsíthető, hogy az egyes kategóriákon belül több háttértényező is meg- 
jelenne, ez természetesen a pszichológiai és rendszertényezőkre is igaz lenne. Ezeknek az eredményeknek a függvényében lehetne általános következtetéseket levonni, ezek hiányában csak a 2011-es évre vonatkozóan lehetett ezt megtenni.

Annyi azonban bizonyos, hogy a szakellátásba kerülés okaival szorosan összefüggnek a speciális szükséglet megállapításának háttértényezői. A családi és a pszichológiai háttértényezők felülreprezentáltsága azt jelzi, hogy komolyan oda kell figyelni ezeknek a gyerekeknek és családoknak az életére, és amikor már szükséges, a legadekvátabb segítségnyújtást kell számukra megadni, ott ahol élnek, saját környezetükben. A mesterséges erőforrások biztosítása arra is kell, hogy irányuljon, hogy a család természetes erőforrásait megerősítse, és előmozdítsa a hatékony problémamegoldást. A gyermeknek, a családnak tehát a gyermekjóléti alapellátás keretei között kell maradni, amennyiben mégis szakellátásba kerül a gyermek, az már valamelyest egyfajta „tüzoltási”segítségnyújtást eredményez. Az alapellátás megerősítése nagyon fontos feladat lenne, az együttmüködéseket fel kellene tartalommal tölteni a szakma oldaláról is. A családgondozók feladatokat, határidőket szabnak meg a családok számára, viszont sok esetben nincsenek meg a forrásaik, eszközeik a cél megvalósításának támogatásához. A szociális munkás „híd szerepét” kell, hogy betöltse, azaz kösse össze a családokat a megfelelő segítségnyújtási formával. Jelzés esetén nagyon fontos lenne átlátnia a családi viszonyokat, megfelelően értelmezni az iskola jelzéseit, és nem utolsósorban a gyermek tüneteinek értelmezésén is nagyon sok múlik. Amennyiben ez nem így történik, már itt megkezdődik a gyermekvédelmi rendszer általi másodlagos veszélyeztetés, amely vezethet a gyermekvédelmi szakellátásba kerüléshez. Éppen ezért nagy hangsúly van a prímer prevención. A legtöbb esetben a családgondozó már akkor kerül kapcsolatba a családdal, amikor probléma jelentkezik. A családgondozás során fontos a napi kapcsolat a gyermekpszichiátriai ambulanciával, a drogambulanciával, a szenvedélybetegek és pszichiátriai betegek közösségi ellátásával, illetve a pszichoterápiát, családterápiát nyújtó szakemberrel. A terápiás programba be lehetne építeni a különbözö területen dolgozó szakemberek, a gyermek és a család rendszeres találkozását, ahol a terápiás profil további alakulását, a tapasztalatokat meg lehetne beszélni. Ezeknek a team-eknek az interdiszciplinaritás kell, hogy a középpontjában álljon.

Természetesen itt is felmerülhet olyan probléma, hogy az adott segítségnyújtás nincs feltöltve tartalommal. A gyermekpszichiátriai ambuláns kezelések gyakran csak gyógyszeres terápiára korlátozódnak, nem biztosítanak mellé megfelelő pszichés vezetést sem a gyermeknek, sem pedig a családnak. Kisebb településeken előfordul, hogy nem biztosítható a család számára családterápia, vagy a gyermek számára pszichoterápia, mert nincs a gyermekjóléti szolgálatnál pszichológus, nincs a közelben pedagógiai szakszolgálat. Ezek a családok a legtöbbször rossz anyagi körülmények között élnek, képtelenek megoldani a heti egykét alkalmas találkozások miatt a 30-40 km-es utak finanszírozását. 
A családi háttértényezők ismerete, a pszichológiai háttértényezők feltárása, és a rendszertényezők megjelenésének elkerülése a legfontosabb feladata a családdal foglalkozó szakembernek. Amennyiben ennek ellenére sem történik változás, a gyermek speciális ellátási igény szerinti nevelése elkerülhetetlenné válik a gyermekvédelmi szakellátásban. A szociális munkás szerepe ekkor is a tanácsadás, továbbá hogy koordinálja a szükséges segítségnyújtások elérését. A pszichiátriai jellegü tünetek kezelésére jelenleg azonban nincs adekvát gyermekvédelmi intézmény, amely a rendszer másodlagos veszélyeztetését megvalósítja, egyrészt azért mert nem létezik, másrészt azért mert felveti a kérdést, a speciális gyermekotthon melyik csoportjába helyezik a gyermeket.

Érdemes lenne feltárni azt, hogy a speciális gyermekotthonok reszocializációs nevelése következtében megoldódnak e a családok járulékos krízisei. Egyrészt következtethetnénk arra, hogy mennyire eredményes a speciális gyermekotthonokban zajló munka, másrészt visszacsatolást jelentene a veszélyeztető tényezőkre, szakellátásba kerülés okaira is.

A tünetek hátterében dolgozó mechanizmusok komplexitása vitathatatlan, további vizsgálódásokat feltételezne, azonban szociális munkásként a családi háttértényezők tudatos alakítása a legfontosabb feladat, függetlenül attól, hogy a gyermek speciális szükségletü, vagy sem.

\section{Felhasznált irodalom:}

1. Bálint Miklós (2007): Hiányosságok a szakellátásban-a gyermek másodlagos veszélyeztetése, Kapocs, 4, 26-30.

2. Józsa Viktor (2007a): Gondolatok a speciális szükséglet megítéléséről, Család, Gyermek, Ifjúság, 3, 20-24.

3. Józsa Viktor (2007b): Szempontok a speciális ellátás értelmezéséhez, Család, Gyermek, Ifjúság, 3, 8-15.

4. Hajdunl Kálmán Margit (2007): Néhány észrevétel a speciális ellátást biztosító szolgáltatásokról, Család, Gyermek, Ifjúság, 3, 18-20

5. Herczog Mária (2007): Speciális szükségletü gyermekek, családok, szakemberek, intézmények, Család, Gyermek, Ifjúság, 3, 6-7.

6. Kálmánchey Márta (2001): Nevelőszülőnél nevelkedő gyermekeknél előforduló pszichés problémák, Család, Gyermek, Ifjúság, 2, 45-53.

7. Molnár László-Dr Radoszáv Miklós (2007): Töredék gondolatok speciális ügyben, Család, Gyermek, Ifjúság, 3, 4-5.

8. Neményi Mária - Messing Vera (2007): Gyermekvédelem és esélyegyenlöség, Kapocs, 1, 2-19. 
9. Rácz Andrea - Szikulai István (2006) (Szerk.): A magyar gyermekvédelmi rendszer helyzete, jövőbeli kilátásai, Nemzeti Család és Szociálpolitikai Intézet CD kiadványa, Budapest.

10. Speciális Ellátás Szakmai Műhely tanulmánya, Budapest Főváros Önkormányzatának Módszertani Gyermekvédelmi Szakszolgálata, 2011, http://www.tegyesz.hu/file/Modszertani_tegyesz/Szakmai_muhelyek/Special is_ellatas_szakmai_muhelye/tanulmany_speci_vegso_korr_2011_szept_keto ldalas.pdf

11. Szikulai István (2004): A magyar gyermekvédelem fejlődésének kulcskérdései- egy lehetséges szakmai stratégia lépései, Kapocs, 5, 58-64.

12. Szöllősi Gábor (2003): A gyermekvédelmi probléma, mint társadalmi konstrukció, Esély, 2, 75-95.

13. Szőtsné Karkus Zsuzsanna, Pap Éva, Pál Kornélia, Jankovics Csaba, Dr. Mirnics Zsuzsanna (2007): Gyermekvédelmi gondoskodásban és családban nevelkedő serdülőkorúak érzelmi intelligenciája, megküzdési stratégiája és szorongása, Család, Gyermek, Ifjúság, 2, 17-22.

\section{Nagy Loránd}

Hajdú-Bihar Megyei Területi Gyermekvédelmi Szakszolgálat 4024 Debrecen, Vármegyeháza u. 9. 